\title{
PENILAIAN ASPEK GREEN HOTEL KELAS MENENGAH (HOTEL BINTANG 1, 2, DAN 3)
}

\author{
Diptya Anggita ${ }^{1}$, Anedya Wardhani ${ }^{2}$, Yodi Danusastro ${ }^{3}$ \\ 1,2 Jurusan Arsitektur Universitas Pancasila \\ ${ }^{3}$ Yodaya Hijau Bestari
}

\begin{abstract}
ABSTRAK
Berdasarkan data STR Global (2015), Pembangunan Hotel di Indonesia termasuk terbanyak kedua se-Asia Pasifik. Pembangunan yang terus menerus tanpa memikirkan dampak lingkungan mendatang akan merusak lingkungan. Jumlah hotel semakin hari semakin meningkat. Berdasarkan data statistik hotel dan tingkat penghunian kamar hotel DKI Jakarta (2014), jumlah hotel di DKI Jakarta pada tahun 2014 ada sebanyak 437 hotel, 35.48\% adalah hotel bintang tiga, 22.12\% hotel bintang dua, 19.82\% hotel bintang empat, dan 10.60\% hotel bintang satu. Jumlah Hotel bintang dan non bintang di Jakarta mengalami peningkatan sebesar $24.50 \%$ sejak tahun 2010-2014. Pembangunan industri pariwisata yang pesat dapat memberikan ancaman yang serius terhadap lingkungan dan sosial budaya. Perkembangan pembangunan hotel juga membuat daerah sekitar Jakarta seperti Bogor, Depok, Tangerang, dan bekasi untuk memenuhi kebutuhan pembangunan industri pariwisata yang pesat. Penelitian ini bertujuan untuk mengetahui sampai sejauh mana aspek green hotel telah diterapkan pada hotel bintang satu, dua, dan tiga di daerah Jabodetabek. Proses penelitian dilakukan dengan pencarian data dan survey lapangan (observasi, wawancara, dan dokumentasi) berdasarkan kriteria yang terdapat pada kuesioner penelitian. Pembahasan pada penelitian yaitu mengenai sampah, energi, HVAC, dan edukasi. Dengan adanya penelitian ini akan memberikan gambaran perkembangan green hotel di Jabodetabek pada masa ini, sehingga pada pembangunan hotel selanjutnya dapat berkembang lebih baik.
\end{abstract}

Kata kunci: Green Hotel, arsitektur hijau, pembangunan hotel.

\section{PENDAHULUAN}

Indonesia adalah negara kepulauan tropis yang kaya akan sumber daya alam dan keanekaragaman hayati. Hal ini menjadi potensi tombak pendapatan negara yaitu aspek pariwisata. Kekayaan tersebut memberikan keunggulan berupa objek wisata yang dapat dinikmati dari Sabang sampai Merauke, sehingga bermacam-macam jenis hotel dan resort banyak dikembangkan di daerah sekitar objek wisata. Menurut Kamus Besar Bahasa Indonesia definisi dari hotel adalah sebuah bangunan berkamar banyak yang disewakan sebagai tempat untuk menginap dan tempat makan orang yang sedang dalam perjalanan. Bentuk akomodasi dikelola secara komersial disediakan bagi setiap orang untuk memperoleh pelayanan, penginapan, makan dan minum.Pengertian tersebut sesuai dengan definisi hotel menurut Keputusan Menteri SK 241/H/70/tahun/1970 bahwa hotel adalah sebuah perusahaan yang memberikan layanan jasa dalam bentuk penginapan/akomodasi serta menyediakan hidangan dan fasilitas lainnya untuk umum yang memenuhi syarat kenyamanan (comfort), rahasia (privacy), dan bertujuan komersional.

Pariwisata memang memiliki peran penting dalam pembangunan nasional maupun regional, terutama pembangunan ekonomi. Namun disisi lain, salah satu tanggung jawab pembangunan dalam konsep keberlanjutan adalah mengedepankan konsep ramah lingkungan. Usaha-usaha terpadu diperlukan untuk mengurangi dampak kerusakan lingkungan yang disebabkan oleh perkembangan industri pariwisata (dalam hal ini perhotelan). Perhotelan mengkonsumsi energi sangat intensif oleh karena itu dalam hal ini memerlukan berbagai usaha penghematan energi. Salah satu upaya tersebut dapat ditinjau dari desain maupun perencanaan fasilitas termasuk dalam hal pemilihan lokasi, pemilihan material bangunan 
dari bahan lokal, pemanfaatan sumber energi terbarukan, pemanfaatan peralatan yang hemat energi, dan lain-lain. Hal ini meliputi berbagai kelas hotel, termasuk kelas menengah yang berada di kisaran bintang satu, dua, dan tiga.

Pemerintah juga telah mengatur tentang bangunan gedung hijau dengan mengeluarkan Peraturan Menteri PUPR no 2/PRT/M/2015. Tertulis bahwa Bangunan Gedung Hijau adalah bangunan gedung yang memenuhi persyaratan bangunan gedung dan memiliki kinerja terukur secara signifikan dalam penghematan energi, air, dan sumber daya lainnya melalui penerapan prinsip bangunan gedung hijau sesuai dengan fungsi dan klasifikasi dalam setiap tahapan penyelenggaraannya. Sedangkan maksud dari Peraturan Menteri tersebut adalah sebagai pedoman bagi penyelenggara bangunan gedung dalam melakukan penyelenggaraan bangunan gedung hijau.

Berdasarkan data yang didapatkan dari Green Building Council Indonesia (GBCl) terdapat 50 bangunan yang masih dalam proses sertifikasi Green Building dan 13 bangunan yang telah memiliki sertifikat Green Building, namun bangunan dengan fungsi sebagai hotel berjumlah 1 (satu) bangunan yang telah tersertifikasi. Terkait dengan peningkatan jumlah hotel bintang satu, dua, dan tiga sebagai deretan jumlah hotel yang meningkat pesat, serta dalam rangka membangun pariwisata Indonesia yang berkelanjutan, perlu adanya Penilaian aspek Green Hotel untuk hotel kelas menengah. Hal tersebutlah yang melatarbelakangi penelitiaan ini yaitu untuk dapat mengetahui sampai sejauh mana aspek green hotel telah diterapkan pada hotel bintang satu, dua, dan tiga di daerah Jabodetabek.

\section{TINJAUAN PUSTAKA}

\section{Sampah}

Menurut Kamus Besar Bahasa Indonesia (KKBI) Sampah adalah barang atau benda yang dibuang karena tidak terpakai lagi dan sebagainya; kotoran seperti daun, kertas. Tujuan pengelolaan sampah untuk: (a) mewujudkan lingkungan yang sehat dan bersih dari sampah; (b) meningkatkan peran serta masyarakat dan pelaku usaha untuk secara aktif mengurangi dan/atau menangani sampah yang berwawasan lingkungan; (c) menjadikan sampah sebagai sumber daya yang memiliki nilai ekonomis; dan (d) mewujudkan pelayanan prima.
Berdasarkan Peraturan Daerah Provinsi Daerah Khusus Ibukota Jakarta no 3 tahun 2013, pengolahan sampah sebelum diangkut ke TPST atau TPA dilakukan dengan cara pengurangan sampah (pembatasan timbulan sampah, pendauran ulang sampah, dan atau pemanfaatan lembali sampah) dan penanganan sampah (menggunakan bahan yang dapat diguna ulang, bahan yang dapat didaur ulang dan/atau bahan yang mudah diurai oleh proses alam).

\section{Energi}

Energi adalah kemampuan untuk mengerjakan sesuatu. Biasanya pada bangunan penggunaan energi terbesar yaitu dengan energi listrik. Konsumsi energi paling besar dialokasikan pada operasional pengondisian suhu ruang dalam gedung berupa pendingin ruangan (air conditioning/AC), transportasi vertikal, dan penerangan. Pengoperasian sistem tersebut dengan menggunakan teknologi dan cara yang tidak efisien dan memiliki dampak yang besar pada perubahan iklim serta pemanasan global karena adanya efek rumah kaca. Untuk memerangi perubahan iklim, perlu adanya praktik-praktik baru, sejak tahap desain hingga pengoperasian gedung, sehingga efisiensi konsumsi energi dapat meningkat dan jejak karbon, potensi pemanasan global, serta potensi penipisan lapisan ozon berkurang.

\section{Air}

Menurut Panduan Penerapan Perangkat Penilaian Bangunan Hijau Greenship yang melatarbelakangi pengaturan air dalam bangunan yaitu Siklus iklim dan curah hujan di Indonesia menjadi terganggu dengan adanya perubahan iklim, pemanasan global, pembalakan hutan, konversi lahan hijau, dan perusakan wetland yang tidak terkendali. Selain itu, hal tersebut juga mengakibatkan keseimbangan neraca air serta ketersediaan air tanah dan air permukaan ikut terganggu. Di saat musim kemarau terjadi kekurangan air, dan di saat musim hujan terjadi banjir. Berdasarkan perhitungan sumber daya air oleh Ditjen Sumber Daya Air DPU, pulau Jawa, Bali, dan NTT mengalami defisit air terutama pada musim kemarau. Defisit ini akan bertambah parah dengan pertambahan penduduk dan meningkatnya kegiatan ekonomi. Selain isu konsumsi air bersih, juga terjadi masalah dalam 
manajemen limbah (grey water dan black water) di kawasan perkotaan, yang daya dukung lingkungannya rendah. Manajemen limbah yang tidak terpadu mengakibatkan pencemaran badan air dan menurunkan kualitas lingkungan.

\section{Edukasi}

Dalam pengoperasian suatu bangunan hijau, sangat diperlukan suatu standar manajemen yang terencana dan baku untuk mengarahkan tindakan dari pelaku operasional bangunan dalam melakukan pengeloalaan gedung agar dapat menunjukkan hasil yang ramah lingkungan. Adanya kategori ini menurut Panduan Penerapan Perangkat Penilaian Bangunan Hijau Greenship juga memberikan penekanan pada pentingnya faktor manusia sebagai salah satu sumber daya yang memegang peranan penting dalam keberlangsungan suatu bangunan hijau.

\section{METODE PENELITIAN}

Penelitian ini melakukan tiga tahapan penelitian, yang pertama adalah dengan melakukan ekplorasi data yang terbagi menjadi dua langkah yaitu studi literatur dan survey lapangan, yaitu dengan observasi, wawancara, dokumentasi, dan pengisian Kuesioner. Kuesioner penilaian disusun dengan melakukan iterasi terhadap penilaian aspek Green Building dari sumber-sumber berikut ini:

1. Peraturan Menteri Pekerjaan Umum no.2 tahun 2015 tentang Bangunan Gedung Hijau

2. Perangkat Penilaian Green Building Greenship versi 1.2 untuk Bangunan baru, dikeluarkan oleh Green Building Council Indonesia.

3. ASEAN Green Hotel Standard, dikeluarkan oleh ASEAN Tourism Standard. ${ }^{1}$

4. Green Globe standard untuk pariwisata berkelanjutan $^{2}$

Dari sumber acuan, dipilih kriteria-kriteria yang seragam dan sesuai untuk dilaksanakan pada skala hotel bintang 3 ke bawah. Kuesioner tersebut didiskusikan dengan responden praktisi ahli Green Building.

\footnotetext{
${ }^{1} \mathrm{http}: / /$ www.asean.org/archive/23074.pdf

${ }^{2}$ http://greenglobe.com/
}

Tahapan kedua dengan melakukan analisis data berdasarkan tahapan ekplorasi data yang didapatkan. Analisis dilakukan dengan metode kualitatif yaitu analisis yang dilakukan dengan mengorganisasikan data, menjabarkannya ke dalam unit-unit, melakukan sintesa, menyusun kedalam pola, memilih mana yang penting dan yang akan dipelajari, dan membuat kesimpulan yang dapat diceritakan kepada orang lain (Sugiono,2007:224). Tahapan yang terakhir adalah pengambilan kesimpulan penelitian.

\section{HASIL SURVEY DAN ANALISIS}

Survei dilakukan dengan pengamatan, penilaian, dan wawancara, dan dilakukan dalam tiga tahap (pencarian hotel untuk disurvei; survei; penulisan hasil survey). Hotel yang telah disurvei berjumlah 10 hotel dan berlokasi di Jabodetabek (Jakarta, Bogor, tangerang, dan Bekasi). Sepuluh hotel tersebut dianggap dapat mewakili hotel-hotel yang ada di Jabodetabek.

Mendapatkan hotel yang mengijinkan untuk survei penelitian tidak mudah. Pencarian dan survey hotel berhasil dilakukan selama kurang lebih selama tiga bulan (87 hari), dari 46 hotel yang telah diajukan untuk survey (melalui via telepon, email, dan pemberian surat langsunghanya),10 hotel yang mensetujui untuk dilakukan penelitian. Hal tersebut dapat disimpulkan bahwa tingkat kehijauan hotel merupakan pembahasan yang sensitif yang tidak mudah untuk dibagikan informasinya bagi hotel kelas menengah (bintang 1, 2, dan 3) karena merupakan bangunan komersial yang hasil informasi mengenai dalam hotel dapat mempengaruhi penjualan hotel tersebut apabila terdengar oleh pihak lain.

Observasi, penilaian, dan wawancara dilakukan sesuai dengan Kuesioner green hotel, yaitu mengenai sampah, energi, air, dan edukasi.

\section{Sampah}

Penilaian mengenai sampah pada hotel terbagi atas empat point penilaian, yaitu pemisahan tempat sampah di area publik sesuai dengan jenisnya; daur ulang sampah nonorganik; pemisahan sampah berbahaya; dan manajemen sampah organik. 
Tabel 1: Penilaian Sampah

\begin{tabular}{|c|c|c|c|c|c|c|c|c|c|c|c|c|}
\hline & \multirow[b]{2}{*}{$\begin{array}{c}\mathrm{ma} \\
\mathrm{x}\end{array}$} & \multicolumn{10}{|c|}{ HOTEL } \\
\hline & & & $\begin{array}{c}\mathrm{SHO} \\
1\end{array}$ & $\begin{array}{c}\mathrm{SHO} \\
2\end{array}$ & $\begin{array}{c}\mathrm{SHO} \\
3\end{array}$ & $\begin{array}{c}\mathrm{SHO} \\
4\end{array}$ & $\begin{array}{c}\mathrm{SHO} \\
5\end{array}$ & $\begin{array}{c}\mathrm{SHO} \\
6\end{array}$ & $\begin{array}{c}\mathrm{SHO} \\
7\end{array}$ & $\begin{array}{c}\mathrm{SHO} \\
8\end{array}$ & $\begin{array}{c}\mathrm{SHO} \\
9\end{array}$ & $\begin{array}{c}\mathrm{SH} 1 \\
0\end{array}$ \\
\hline 1 & $\begin{array}{l}\text { Separate bins in } \\
\text { public areas for } \\
\text { different waste } \\
\text { types. }\end{array}$ & 5 & 4 & 0 & 0 & 5 & 5 & 3 & 5 & 0 & 0 & 0 \\
\hline 2 & $\begin{array}{l}\text { Non-organic waste } \\
\text { are recycled. }\end{array}$ & 10 & 0 & 0 & 0 & 0 & 1 & 0 & 0 & 0 & 0 & 0 \\
\hline 3 & $\begin{array}{l}\text { Hazardous material } \\
\text { (B3) are safely stored } \\
\text { and disposed of. }\end{array}$ & 5 & 4 & 0 & 0 & 5 & 5 & 1 & 3 & 2 & 5 & 0 \\
\hline 4 & $\begin{array}{l}\text { Organic waste is } \\
\text { managed. }\end{array}$ & 10 & 0 & 0 & 0 & 0 & 0 & 0 & 0 & 0 & 0 & 0 \\
\hline & & 30 & 8 & 0 & 0 & 10 & 11 & 4 & 8 & 2 & 5 & 0 \\
\hline
\end{tabular}

Hasil survei mengenai manajemen pembuangan sampah tidak ada yang mencapai nilai maksimal. Melihat poin pertama mengenai pemisahan sampah di area publik hanya terdapat dua hotel yang melakukan pemisahan sampah sesuai dengan isinya; satu hotel melakukan pemisahan sampah namun isi sampah tidak sesuai dengan jenisnya; dan lima hotel tidak membagi tempat sampah di area publik. Poin kedua mengenai daur ulang sampah non-organik hanya dilakukan oleh satu hotel namun pada saat-saat tertentu seperti untuk hiasan interior hotel pada saat acara hari Kemerdekaan RI dengan menggunakan botol bekas aqua sebagai gapura pintu hotel. Pada point ke tiga mengenai pemisahan sampah berbahaya, seperti pembuangan lampu bolam. Hasil survei menunjukan bahwa terdapat tiga hotel yang tidak memisahkan sampah B3; dua

Tabel 2: Penilaian Energi hotel yang melakukan pemisahan sampah B3dan memiliki petugas khusus untuk pengambilannya; dan sisanya tidak dipisahkan. Pada point keempat mengenai manajemen sampah organik, berdasarkan hasil survey keseluruhan hotel yang telah disurvei tidak mengolah ataupun mendaur ulang sampah organik. Sehingga dapat disimpulkan bahwa pencapaian nilai maksimal hanya sekitar $16 \%$ (total keseluruhan maksimum nilai pada 10 hotel dibandingkan dengan nilai yang didapatkan).

\section{Energi}

Pada penilaian mengenai energi pada hotel terbagi atas empat point penilaian, yaitu review energi, perawatan peralatan HVAC, instalasi penerangan hemat energi, dan instalasi peralatan hemat energi.

\begin{tabular}{|c|c|c|c|c|c|c|c|c|c|c|c|c|}
\hline & & \multicolumn{10}{|c|}{ HOTEL } \\
\hline & & $\begin{array}{c}\text { Ma } \\
x\end{array}$ & $\begin{array}{c}\mathrm{SHO} \\
1\end{array}$ & $\begin{array}{c}\mathrm{SHO} \\
2\end{array}$ & $\begin{array}{c}\mathrm{SHO} \\
3\end{array}$ & $\begin{array}{c}\mathrm{SHO} \\
4\end{array}$ & $\begin{array}{c}\mathrm{SHO} \\
5\end{array}$ & $\begin{array}{c}\mathrm{SHO} \\
6\end{array}$ & $\begin{array}{c}\mathrm{SHO} \\
7\end{array}$ & $\begin{array}{c}\mathrm{SHO} \\
8\end{array}$ & $\begin{array}{c}\mathrm{SHO} \\
9\end{array}$ & $\begin{array}{c}\mathrm{SH} 1 \\
0\end{array}$ \\
\hline 1 & $\begin{array}{l}\text { Energy use has been } \\
\text { reviewed and } \\
\text { opportunities for } \\
\text { savings have been } \\
\text { identified. }\end{array}$ & 10 & 0 & 7 & 0 & 5 & 10 & 0 & 5 & 1 & 1 & 0 \\
\hline 2 & $\begin{array}{l}\text { HVAC plant and } \\
\text { other equipment } \\
\text { regularly maintained. }\end{array}$ & 5 & 5 & 5 & 5 & 5 & 5 & 5 & 5 & 5 & 5 & 5 \\
\hline 3 & $\begin{array}{l}\text { Energy saving } \\
\text { lighting installed. }\end{array}$ & 10 & 3 & 5 & 0 & 5 & 5 & 0 & 5 & 7 & 6 & 0 \\
\hline
\end{tabular}




\begin{tabular}{|l|l|c|c|c|c|c|c|c|c|c|c|c|}
\hline 4 & $\begin{array}{l}\text { Energy saving } \\
\text { equipment installed. }\end{array}$ & $\mathbf{5}$ & 0 & 3 & 0 & 3 & 2 & 3 & 4 & 2 & 2 & 0 \\
\hline & & $\mathbf{3 0}$ & $\mathbf{8}$ & $\mathbf{2 0}$ & $\mathbf{5}$ & $\mathbf{1 8}$ & $\mathbf{2 2}$ & $\mathbf{8}$ & $\mathbf{1 9}$ & $\mathbf{1 5}$ & $\mathbf{1 4}$ & $\mathbf{5}$ \\
\hline
\end{tabular}

Hasil survey energi pada hotel yang telah disurvei memperlihatkan bahwa tidak ada yang mencapai nilai maksimal. Pada point pertama mengenai review penggunaan energi pada hotel hanya dilakukan oleh beberapa hotel. Hasil review energi yang dilakukan oleh pihak hotel tersebut digunakan untuk rencana penghematan energi selanjutnya atau mempertahankan penggunaan energi pada target yang telah ditentukan. Namun terdapat hotel yang melakukan review energi dan pengajuan rencana untuk penghematan energi pada bangunan, namun sering terkendala oleh dana. Pada point ketiga mengenai perawatan peralatan HVAC. Hasil survei memperlihatkan bahwa semua hotel melakukan pengecekan pada peralatan HVAC minimal 2-3 bulan sekali. Pada point ke empat mengenai penggunaan lampu hemat energi. Hasil survey memperlihatkan bahwa tidak ada hotel yang menggunakan LED pada keseluruhan penerangan. LED yang terpasang biasanya teletak di dalam kamar, seperti pada lampu tidur, ruang pertemuan, dan pada lift hotel. Namun terdapat beberapa hotel yang sedang dalam proses penggantian keseluruhan lampu dengan LED dan secara bertahap karena terkait dengan masalah dana. Pada point terakhir mengenai penggunaan alat yang hemat energi.
Hasil survei menunjukan bahwa pada beberapa hotel telah melakukan beberapa usaha untuk penghematan energi, seperti menggunakan lift hemat energi dan pemasangan kunci kamar dengan menggunakan kartu sekaligus untuk menyalakan listrik dalam kamar. Terdapat juga beberapa usaha penghematan energi lainnya seperti pengaturan menyalakan lampu dan lift sesuai dengan jadwal, seperti lampu baru akan dinyalakan pada malam hari dan menyalakan hanya satu lift setelah jam 09.00 malam atau apabila pengunjung hotel tidak terlalu banyak. Sehingga dapat disimpulkan bahwa pencapaian nilai maksimal hanya sekitar $45 \%$ (total keseluruhan maksimum nilai pada 10 hotel dibandingkan dengan nilai yang didapatkan).

\section{Air}

Pada penilaian mengenai manejemen air pada hotel terbagi atas lima point penilaian, yaitu pelatihan karyawan untuk meminimalisasi pembuangan air, penggunaan low-flush pada toilet, program penggunaan kembali handuk/linen, penggunaan grey water untuk irigasi tanaman, dan menggunaan grease traps pada sinks.

Tabel 3: Penilaian Air

\begin{tabular}{|c|c|c|c|c|c|c|c|c|c|c|c|c|}
\hline & \multirow[b]{2}{*}{$\begin{array}{c}\mathrm{ma} \\
\mathrm{x}\end{array}$} & \multicolumn{10}{|c|}{ HOTEL } \\
\hline & & & $\begin{array}{c}\mathrm{SHO} \\
1\end{array}$ & $\begin{array}{c}\mathrm{SHO} \\
2\end{array}$ & $\begin{array}{c}\mathrm{SHO} \\
3\end{array}$ & $\begin{array}{c}\mathrm{SHO} \\
4\end{array}$ & $\begin{array}{c}\mathrm{SHO} \\
5\end{array}$ & $\begin{array}{c}\mathrm{SHO} \\
6\end{array}$ & $\begin{array}{c}\mathrm{SHO} \\
7\end{array}$ & $\begin{array}{c}\mathrm{SHO} \\
8\end{array}$ & $\begin{array}{c}\mathrm{SHO} \\
9\end{array}$ & $\begin{array}{c}\mathrm{SH} 1 \\
0\end{array}$ \\
\hline 1 & $\begin{array}{l}\text { Staff training to } \\
\text { minimise waste of } \\
\text { water by } \\
\text { housekeeping, } \\
\text { catering staff etc. } \\
\text { carried out regularly. }\end{array}$ & 5 & 0 & 3 & 0 & 3 & 0 & 0 & 0 & 0 & 3 & 0 \\
\hline 2 & $\begin{array}{l}\text { Installation of low- } \\
\text { flush WCs to reduce } \\
\text { number of litres per } \\
\text { flush. }\end{array}$ & 10 & 6 & 9 & 0 & 10 & 10 & 10 & 10 & 10 & 0 & 0 \\
\hline 3 & $\begin{array}{l}\text { Towel/linen reuse } \\
\text { programme in } \\
\text { operation. }\end{array}$ & 5 & 0 & 0 & 0 & 5 & 0 & 0 & 0 & 0 & 1 & 0 \\
\hline 4 & Recycling water by & 5 & 0 & 0 & 0 & 5 & 0 & 0 & 0 & 0 & 0 & 0 \\
\hline
\end{tabular}




\begin{tabular}{|l|l|c|c|c|c|c|c|c|c|c|c|c|}
\hline $\begin{array}{l}\text { irrigating plants with } \\
\text { grey water. }\end{array}$ & & & & & & & & & & & \\
\hline $\mathbf{5}$ & $\begin{array}{l}\text { Grease traps in place } \\
\text { and maintained in } \\
\text { kitchen sinks. }\end{array}$ & $\mathbf{5}$ & 2 & 5 & 0 & 5 & 5 & 5 & 5 & 5 & 5 & 0 \\
\hline & & $\mathbf{3 0}$ & $\mathbf{8}$ & $\mathbf{1 7}$ & $\mathbf{0}$ & $\mathbf{2 8}$ & $\mathbf{1 5}$ & $\mathbf{1 5}$ & $\mathbf{1 5}$ & $\mathbf{1 5}$ & $\mathbf{9}$ & $\mathbf{0}$ \\
\hline
\end{tabular}

Hasil survey mengenai manajemen air pada hotel memperlihatkan bahwa hanya terdapat satu hotel yang hampir mencapai nilai maksimal. Pada point pertama mengenai pelatihan karyawan, hasil survei memperlihatkan bahwa semua hotel tidak melakukan pelatihan khusus untuk penggunaan air, namun telah memasukan peraturan penggunaan air dalam SOP hotel. Pada point kedua mengenai pemasangan low-flush pada toilet, hasil survei memperlihatkan bahwa terdapat lima hotel yang telah menggunakan low-flush pada keseluruhan toiletnya dan terdapat tiga hotel yang keseluruhan toiletnya tidak menggunakan lowflush, sedangkan sisanya jumlah toilet yang telah menggunakan low-flush hanya sebagian dari keseluruhan toilet. Hotel yang telah menggunakan keseluruhan toiletnya dengan low-flush merupakan hotel baru. Point ketiga mengenai penggunaan handuk/linen kembali, menurut hasil survei hanya terdapat satu hotel yang telah memberikan informasi berupa tulisan untuk menggunakan handuk/linen untuk digunakan kembali dan terdapat satu hotel yang menggunakan peraturan bahwa hotel akan mengganti handuk secara otomatis apabila pengunjung menginap lebih dari dua hari. Point keempat mengenai penggunaan grey water untuk irigasi tanaman, hasil survey menunjukan bahwa hanya terdapat satu hotel yang telah menggunakan grey water untuk irigasi tanaman. Pada point terakhir mengenai penggunaan grease traps pada sinks, hasil survey menunjukan bahwa hampir keseluruhan hotel telah menggunakan grease traps (7 hotel) dan terdapat dua hotel yang belum menggunakan grease traps, dan sisanya tidak keseluruhan sink menggunakan grease traps. Sehingga dapat disimpulkan bahwa pencapaian nilai maksimal hanya sekitar $41 \%$ (total keseluruhan maksimum nilai pada 10 hotel dibandingkan dengan nilai yang didapatkan).

\section{Edukasi}

Pada penilaian mengenai edukasi pada hotel terbagi atas dua point penilaian, yaitu program pelatihan lingkungan untuk karyawan dan informasi untuk pengunjung mengenai program lingkungan.

Tabel 4: Penilaian Pendidikan

\begin{tabular}{|l|l|c|c|c|c|c|c|c|c|c|c|c|}
\hline \multicolumn{2}{|c|}{} & & \multicolumn{10}{|c|}{ HOTEL } \\
\cline { 2 - 13 } & $\begin{array}{c}\mathrm{ma} \\
\mathrm{x}\end{array}$ & $\begin{array}{c}\mathrm{SHO} \\
1\end{array}$ & $\begin{array}{c}\mathrm{SHO} \\
2\end{array}$ & $\begin{array}{c}\mathrm{SHO} \\
3\end{array}$ & $\begin{array}{c}\mathrm{SHO} \\
4\end{array}$ & $\begin{array}{c}\text { SHO } \\
5\end{array}$ & $\begin{array}{c}\text { SHO } \\
6\end{array}$ & $\begin{array}{c}\text { SHO } \\
7\end{array}$ & $\begin{array}{c}\text { SHO } \\
8\end{array}$ & $\begin{array}{c}\text { SHO } \\
9\end{array}$ & $\begin{array}{c}\text { SH1 } \\
0\end{array}$ \\
\hline $\mathbf{1}$ & $\begin{array}{l}\text { Staff 'environmental' } \\
\text { training programmes } \\
\text { in place. }\end{array}$ & $\mathbf{5}$ & 0 & 5 & 0 & 5 & 5 & 0 & 5 & 0 & 5 & 0 \\
\hline $\mathbf{2}$ & $\begin{array}{l}\text { Guests kept } \\
\text { informed of } \\
\text { environmental } \\
\text { programme. }\end{array}$ & $\mathbf{5}$ & 0 & 0 & 0 & 0 & 5 & 0 & 0 & 0 & 1 & 0 \\
\hline & & $\mathbf{1 0}$ & $\mathbf{0}$ & $\mathbf{5}$ & $\mathbf{0}$ & $\mathbf{5}$ & $\mathbf{1 0}$ & $\mathbf{0}$ & $\mathbf{5}$ & $\mathbf{0}$ & $\mathbf{6}$ & $\mathbf{0}$ \\
\hline
\end{tabular}

Hasil survey mengenai pendidikan pada hotel memperlihatkan bahwa hanya terdapat satu hotel yang dapat mencapai nilai maksimal. Pada point pertama mengenai pelatihan lingkungan, hasil survei menunjukan bahwa terdapat lima hotel yang telah menggunakan program pelatihan untuk karyawannya. Berdasarkan hasil wawancara menyebutkan bahwa telah ada peraturan dari Pemerintah Daerah untuk selalu meninjau aspek lingkungan 
hotel-hotel yang telah terbangun. Sedangkan poin kedua mengenai informasi kepada pengunjung, berdasarkan hasil survey hanya satu hotel yang memberikan informasi tersebut kepada pengunjung, sedang nlai yang tidak maksimal dikarenakan pemberian informasi tersebut (seperti stiker) hanya diberikan di area service yang hanya ditujukan untuk karyawan.Sehingga dapat disimpulkan bahwa pencapaian nilai maksimal hanya sekitar $31 \%$ (total keseluruhan maksimum nilai pada 10 hotel dibandingkan dengan nilai yang didapatkan).

\section{KESIMPULAN}

Melihat dari hasil analisis di atas aspek green hotel pada point sampah hanya dapat tercukupi sekitar $16 \%$ dari nilai maksimal penilaian, sedangkan pada point energi sekitar $45 \%$ dari nilai maksimal penilaian, pada point air sekitar $41 \%$ dari nilai maksimal penilaian, dan yang terakhir point edukasi sekitar $31 \%$ dari nilai maksimal penilaian.Sehingga dapat sisimpulkan bahwa hanya $34 \%$ yang telah mencukupi kriteria green hotel di daerah Jabodetabek. Point terendah yang didapatkan yaitu pada bidang persampahan. Hal tersebut memperlihatkan bahwa kepedulian pada bidang persampahan masih sangat minim dan yang paling difokuskan pada hotel adalah pada energi bangunan yang digunakan.

\section{DAFTAR PUSTAKA}

Prasasto Satwiko, 2008. FISIKA BANGUNAN. Penerbit: Andi, Yogyakarta.

Heinz Frick, Tri Hesti M, 2006. ARSITEKTUR EKOLOGIS. Penerbit: Kanisius.

Peraturan Menteri PUPR no 2/PRT/M/2015

Tim Rating $\mathrm{GBCl}$, 2010. Panduan Penerapan Perangkat Penilaian Bangunan Hijau Greenship Versi 1.0. Jakarta.

Green Building Council Indonesia, 2013. Perangkat Penilaian Green Building Greenship versi 1.2 untuk Bangunan baru. Jakarta.

Peraturan Daerah Provinsi Daerah Khusus Ibukota Jakarta no 3 tahun 2013.

Peraturan Menteri PUPR no 2/PRT/M/2015

Surat tertulis hasil didiskusikan dengan responden praktisi ahli Green Building.

http://www.asean.org/archive/23074.pdf http://greenglobe.com/ 
